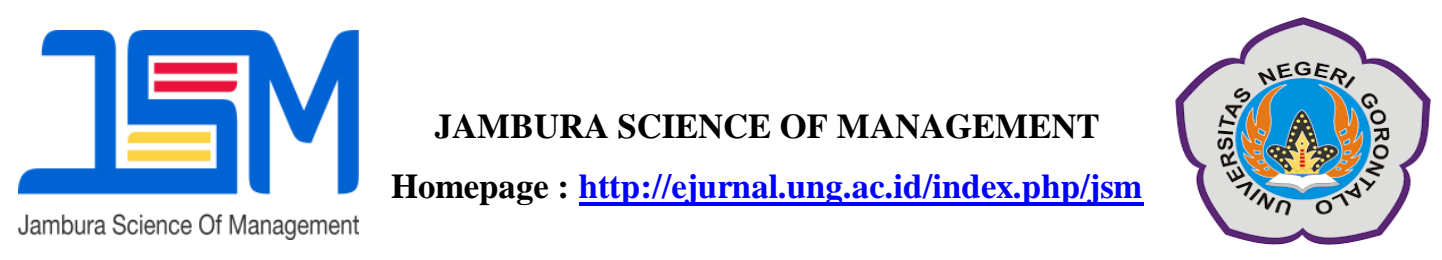

\title{
Do profitability ratio and market ratio contribute to explain the movement of stock prices of transport companies?
}

\author{
Sitty Shandragies Usman ${ }^{1}$, Idham Masri Ishak ${ }^{2}$, Selvi, Selvi ${ }^{3}$ \\ ${ }^{1,2,3}$ Department of Management, Economic Faculty, Gorontalo State University \\ E-mail: Sittyusman06@gmail.com
}

\begin{abstract}
:
This study aims to determine the effect of profitability ratios and market ratios on stock prices on transportation companies listed on the Indonesia Stock Exchange with the study period of 2013-2017. Profitability ratios used in this study are Return On Assets (ROA) and Return On Investment (ROI) and Market Ratios used in this study are Price Earning Ratio (PER) and Market to Book Value (MBV) to stock prices. The sample in this study were 24 transportation companies listed on the IDX. The data analysis method in this research is multiple linear regression which aims to obtain a comprehensive picture of the effect of the Profitability Ratio and Market Ratio variables on stock prices using the SPSS program. The results showed that only partially market ratio variables had an effect on stock prices both measured by PER and MBV while profitability ratio variables measured by ROA and ROI simultaneously had no effect on stock prices. Simultaneously shows that all variables namely profitability ratios and market ratios together have an influence on the stock prices of transport companies listed on the Indonesia Stock Exchange in 2013-2017.
\end{abstract}

Keywords: Profitability Ratio; Market Ratio; Stock price.

The most chosen investment instrument by investors and is a popular investment product, stock. Stocks are a sign of capital participation in a limited liability company, while stock prices in general are prices that arise from the results of movements in demand and supply in the stock market. Basically, investors want stock prices that are stable and tend to rise from time to time, if the stock price has decreased continuously means it can reduce the value of the issuer in the eyes of investors or potential investors (Utari, 2014; Kasmir, 2017, Sutrisno, 2013; Atim, 2017).

In transportation companies there are several companies whose share prices have continued to decline over the past few years, such as the transportation company PT. Garuda Indonesia Tbk (GIAA), PT. Indonesia Transport \& Infrastructure Tbk (IATA), PT. Mitra International Resources Tbk (MIRA), and PT. Rig Tenders Indonesia Tbk (RIGS). Changes in stock prices are influenced by several factors, one of which is the 
announcement of the company's financial statements. Information on the financial statements needed by investors is in the form of earnings assessed by profitability ratios with Return On Asset (ROA) and Return On Investment (ROI) measurement indicators and is influenced by investor confidence in companies valued by market ratios with the measurement indicators Price Earning Ratio (PER) and Market to Book Value (MBV) (Tyas, Rizqi, and Saputra, 2016; Angga; 2011; Abhimada, et al , 2016; Avdalovic, Snezana, and Milenkovic, 2017;

Based on the description above, this study aims to determine the Effect of Profitability Ratios and Market Ratios on Stock Prices on Transportation Companies Registered on the Indonesian Stock Exchange in 2013-2017.

\section{RESULT AND DISCUSSION}

Based on the SPSS output display, the calculated t-value for the Profitability Ratio variable uses the ROA indicator of 0.723 , then the t-table value of 1.660 or $t-$ count is much smaller than the $t$ table. The significance value of ROA is 0.471 or far greater than the alpha probability value with a confidence level of $5 \%$. Furthermore, the t-value obtained for the Profitability Ratio variable using the ROI indicator of 0.647 , known $t$ table value of 1.660 or $t$ count is much smaller than $t$ table. Significant value of ROI of 0.519 or far greater than the alpha probability value with a confidence level of $5 \%$.

\section{METHOD}

This type of research used in this study is a quantitative descriptive approach because it gives a description of the results of the study. The population in this study were all transportation companies listed on the Indonesia Stock Exchange which consisted of 35 companies with a research sample consisting of 24 transportation companies that met the criteria. The data used in this study are in the form of annual reports and financial statements of transportation companies listed on the Indonesia Stock Exchange for the 20132017 period that are accessed through the official website of the Indonesia Stock Exchange.

Based on this explanation it can be explained that the Profitability Ratio using both ROA and ROI does not have a significant effect on the Stock Prices of Transportation companies listed on the Indonesia Stock Exchange between 2013 and 2017, or in other words $\mathrm{H} 0$ is accepted and $\mathrm{H} 1$ is rejected, which means the hypotheses compiled previously rejected.

The absence of the effect of the ratio of profitability to stock prices in this study with a sample of transportation companies from 2013 to 2017 can be caused by several factors, among others, stock performance does not always coincide with company fundamentals and most likely the price of transportation company shares during the study was influenced by 
technical factors such as the quality and services provided, other than that weaknesses in the management of company assets cause a decrease in the rate of return on investment in transportation companies.

Based on descriptive results from research data, it shows that the transportation companies during the study period 2013 to 2017 were not able to provide a large level of profit where the profits were still very low, although the average assets of the transport company during the study period were quite large but were unable to generate profits and some transportation companies only suffer losses. This means that the profitability ratio in this study does not encourage an increase in stock prices, because the average profitability is calculated using both ROA and ROI shows very low numbers and even negative ones.

Based on the SPSS output display, the calculated t-value for Market Ratio variable uses PER indicator of 2.361, then it is known that the $t$ table value is 1.660 or $\mathrm{t}$ arithmetic is far greater than $\mathrm{t}$ table. The significance value of PER is 0.020 or much smaller than the alpha probability value with a confidence level of $5 \%$. Furthermore, t-value is obtained for the Market Ratio variable using the MBV indicator of 2.459 , then the t-table value of 1.660 is known or the t-count is much greater than $t$ table. Significant value of ROI of 0.015 or much smaller than the alpha probability value with a confidence level of $5 \%$.
Based on this explanation it can be explained that the Market Ratio using both PER and MBV has a significant influence on the Stock Prices of Transportation companies listed on the Indonesia Stock Exchange in 2013 to 2017, or in other words $\mathrm{H} 1$ is accepted and H0 is rejected, which means the hypothesis prepared earlier be accepted.

The company's valuation by investors will greatly influence investment decisions, because investors will invest in companies that have good performance and have confidence in the eyes of investors. The influence of market ratios on stock prices in this study is due to the measurement of market ratios with the two indicators using a comparison of stock prices so that there is a relationship with the dependent variable namely stock prices. This means that investors in predicting the stock prices of transportation companies also pay attention to the public's assessment of the company (issuer) in terms of market ratios, especially the PER and MBV value generated by the company, so the market ratio in this study encourages an increase in share prices and can be used as a benchmark in start an investment.

Based on the output data it is known that the calculated $\mathrm{F}$ value is 2.686 . The F-table at a significance level of $5 \%$ is known through Nk-1, where " $\mathrm{N}$ " is the total sample of $120, \mathrm{k}$ (number of independent variables) is 2 , and the degree of freedom of numerator (df1) is 1 so 120 $2-1=117$, it is known that the table $\mathrm{F}$ value is 2.45 . Furthermore, in accordance 
with the previous explanation, it must compare the calculated $\mathrm{F}$ value with the $\mathrm{F}$ value of the table. If the two $F$ values are compared, the F-calculated value obtained is greater than the F-table value. Based on these tests, it can be concluded that the previously prepared hypothesis was accepted, or H1 was accepted and $\mathrm{H} 0$ was rejected.

\section{CONCLUSION}

Based on the results of the study, the following conclusions can be drawn:

The instruments in the research variables used are profitability ratios (ROA and ROI), and market ratios (PER and MBV), as well as the share prices of transport companies in 2013 to 2017, are quite good, reliability can be seen from the results of the pre-test requirements of research through the normality test, test classical assumptions, and nonmulticollinity tests.

Partially (individually), the profitability ratio variable with ROA and ROI indicators simultaneously does not have a significant effect, for the market ratio variable with PER and MBV indicators simultaneously has a significant influence on the movement of stock prices of transport companies listed on the Indonesia Stock Exchange in the year 2013-2017.

All independent variables profitability ratios (ROA and ROI) and market ratios (PER and MBV) have a joint effect on transport company stock prices as evidenced by the calculated $\mathrm{F}$ value greater than the $\mathrm{F}$ table value.

$5.4 \%$ of all independent variables contribute to explain the movement of stock prices of transport companies.

\section{REFERENCESS}

Aning Tyas, Rizqi dan Rishi Septa Saputra. 2016. Analisis Pengaruh Profitabilitas Terhadap Harga Saham (Studi Kasus Perusahaan Telekomunikasi yang Terdaftar di Bursa Efek Indonesia (BEI) Periode 2012-2014). Jurnal Online Insan Akuntan.

Bayu Saputra, Angga. 2011. Analisis Pengaruh Rasio Keuangan Terhadap Harga Saham (Studi Empiris pada Perusahaan Manufaktur yang Terdaftar di Bursa Efek Jakarta. Skripsi.

Djazuli, Atim. 2017. The Relevance of Leverage, Profitability, Market Performance, and Macroeconomic to Stock Price. EKOBIS - Ekonomi Bisnis.

Gatuth Satryo, Abhimada dkk. 2016. The Influence of Profitability Ratio, Market Ratio, and Solvency Ratio on The Share Prices of Companies 
Listed on LQ 45 Index. The Indonesian Accounting Review.

Kasmir. 2017. Analisis Laporan Keuangan. Edisi Pertama. PT Rajagrafindo Persada, Jakarta.

Milosevic Avdalovic, Snezana dan Ivan

Milenkovic. 2017. Impact of

Company Performances on The Stock Price : An Empirical Analysis on Select Companies in Serbia. Original Scientific Paper.

Sutrisno. 2013. Manajemen Keuangan Teori Konsep \& Aplikasi. Edisi pertama. Ekonisia, Yogyakarta.

Utari, Dewi dkk. 2014. Manajemen Keuangan. Edisi Revisi. Mitra Wacana Media, Jakarta. 